\title{
Perception of intern doctors about the newly introduced assessment system in the final professional MBBS examination
}

\author{
Prof. Dr. Fatima Parveen Chowdhury ${ }^{I}$, Dr. A K M Asaduzzaman' ${ }^{2}$ Dr. Tahmina Nargis ${ }^{3}$, Dr. Chowdhury Nasrath Munir Abeer ${ }^{4}$
}

\begin{abstract}
It was a descriptive study. The objective was to find out the perception of intern doctors regarding newly introduced assessment system in final professional MBBS examination which was held in July 2011. Data were collected from 500 inter doctors of selected medical colleges by using self administered questionnaire.

It was found that majority ( $84 \%$ ) of the respondent expressed their satisfaction with the newly introduced assessment method .Of the students $95.5 \%$ mentioned that SAQ is better than Essay questions. Inclusion of MCQ, SOE and OSCE in examination is worthy was opined by about $86.6 \%, 81.7 \%, 78 \%$ of the students respectively. Nearly eighty nine $(89 \%)$ percent respondents thought that adding of a certain percentage of mark of formative assessment in final examination is better. About $29 \%$ of respondents said that examination phobia in oral /viva is not reduced by introducing SOE, $26.2 \%$ believed that all examinees are not judged in same standard by examiners by means of OSCE and $31 \%$ respondents believed that result of examination in SOE, some extent depends upon the examiners desire and intention. So, it reveals that the new assessment method is not implemented properly. Students also identified strengths and weakness of the new assessment.
\end{abstract}

\section{Introduction}

Bangladesh is a developing country. There are lots of problems in the field of health services in the country. Now, it is clear that we need more competent doctors. So, for the sake of producing competent doctors, we have to ensure appropriate curriculum, good teaching \& learning environment and efficient assessment system. Assessment is the best way through which we can measure students learning. To change curricula or instructional methods without changing the examination system will achieve nothing. (Miller 1977). We are very fortunate that in our newly introduced undergraduate curriculum both the instructional methods and assessment systems are changed, so we expect that there will be more profound impact upon the nature of learning. Assessment is a matter of measurement and it has a powerful influence over learning (Sood 1995).One of the most important responsibilities of teachers is to find out how much students have learned and assessment is the process to find out that (Abbatt. 1980). A number of factors affect learning, like quality of teaching, approaches to learning, availability and access to resources etc. The most powerful single influence on learning is probably the assessment system, which is used (Crooks

\footnotetext{
${ }^{1}$ Director, Centre for Medical Education, Mohakhali, Dhaka. Principal Investigator

${ }^{2}$ Assistant Professor, Centre for Medical Education, Mohakhali, Dhaka.

Co-investigator

${ }^{3}$ Lecturer, Centre for Medical Education, Mohakhali, Dhaka.

${ }^{4}$ Lecturer, M H Samorita Medical College, Dental Unit, Dhaka.
}

Contact Address: Prof. Dr. Fatima Parveen Chowdhury

Cell: 01552202059, E-mail: prof.parveen@gmail.com
1988 and Gibbs 1992).

The newly introduced curriculum which is implemented in March 2003, there is a tremendous changes in written examination and also in traditional oral \& practical examination in each subject as follows-

The newly introduced curriculum which is implemented in March 2003, there is a tremendous changes in written examination and also in traditional oral \& practical examination in each subject as follows-

- $10 \%$ marks in written examination of each paper of each subject are allocated for formative assessment.

- $20 \%$ marks are allocated for MCQ for each paper

- $70 \%$ marks are allocated for Short answer question (SAQ).

- Traditional oral examination have been replaced by structured oral examination (SOE)

- In practice examination Objective structured clinical examination (OSCE) is introduced.

- The study was designed to explore the intern doctor's perception of the standard \& quality of the assessment of final professional MBBS examination according to new curriculum 2002. Therefore, their views in this regard are important and needed for evaluation of the assessment technique.

\section{Methodology}

This cross sectional descriptive study was carried out in purposively selected seven governments and seven private medical colleges .Respondents were conveniently selected 500 intern doctors who appeared in the newly introduced assessment system in final professional MBBS examination held in July 2011. A self administered questionnaire was developed with reference to the literature and consultation

Bangladesh Journal of Medical Education 2012;3(1):22-25. (C) 2012 Parveen et al., publisher and licensee Association for Medical Education. This is an Open Access article which permits unrestricted non-commercial use, provided the original work is properly cited. 
with the experts to address all the relevant aspects and finalized after pretesting. Before administering the questionnaire the purpose of the study was clearly explained to the intern doctors, so that they could answer the questions to the best of their perception

\section{Results}

Table 1 shows that $95.4 \%$ intern doctors mentioned that short answer question in written examination is better than essay questions, and $86.6 \%$ of the respondents thought that inclusion of MCQ in written examination is better, $81.7 \%$ students mentioned that inclusion of structured oral examination in new method is better, $78 \%$ of the respondents thought that inclusion of objective structured clinical examination (OSCE) in new assessment system is better, and $88.9 \%$ intern doctors were in favour of the addition of certain percentage of formative assessment's marks to the final examination.

Table 2 shows that $89.2 \%$ of the respondents agreed that in new assessment system SAQ in written examination inclined students to understand the content rather than memorizing. About $81.40 \%$ of the respondents disagreed with the opinion that it is easier to pass written examination by memorizing a few number of questions answers in new assessment method, and $72.4 \%$ of the respondents agreed with the opinion that it is possible to include all content areas in written examination of new assessment method.

Ninety two percent of the respondents agreed that there is scope of good scoring in MCQ, $67.8 \%$ of the respondents agreed that it is easier to find out the correct answer in MCQ because alternatives are given.

About $57.2 \%$ of the respondents agreed that result of examination in SOE is not dependent on the desire of the examiner, $59.6 \%$ of the respondents agreed with the statement that all students are evaluated equally by the examiners in SOE. Fifty one percent of the respondents agreed with the opinion that all students have to answer equal number of questions in SOE, $64.6 \%$ of the respondents agreed with the opinion that it is possible to judge a student completely by SOE, and only $50.6 \%$ of the respondents agreed with the opinion that student phobia regarding oral/viva examination is reduced by introducing SOE.

About $65.6 \%$ of the respondents agreed with the statement that students are more attentive in acquiring necessary practical skill due to OSCE, $77.2 \%$ of the respondents agreed that it is possible to judge all necessary practical skill in OSCE, $55.4 \%$ of the respondents agreed with the statement that all students were judged in a same standard by examiners by means of OSCE, and $56.6 \%$ of the respondents agreed with the marks of formative assessment on daily attendance in the class make students more interested in attending the class regularly.

About eighty five percent agreed with the statement that they are satisfied with the new assessment system
Table 1. Distribution of the respondents according to their opinion about whether the different methods of assessment system worthy

Strengths of the new assessment method as identified by the students:

\begin{tabular}{|c|c|c|c|}
\hline $\begin{array}{l}\text { opinion about whether the } \\
\text { different methods of } \\
\text { assessment system worthy }\end{array}$ & yes & no & total \\
\hline $\begin{array}{l}\text { Shor } \\
\text { is be }\end{array}$ & $\begin{array}{c}477 \\
(95.4) \\
\end{array}$ & $\begin{array}{c}23 \\
(4.6) \\
\end{array}$ & $\begin{array}{c}500 \\
(100)\end{array}$ \\
\hline $\begin{array}{l}\text { whether inclusion of } \mathrm{N} \\
\text { written examination of } \\
\text { assessment system is } \mathrm{w}\end{array}$ & $\begin{array}{c}438 \\
(86.6)\end{array}$ & $\begin{array}{c}62 \\
(12.4)\end{array}$ & $\begin{array}{c}500 \\
(100)\end{array}$ \\
\hline $\begin{array}{l}\text { whether inclusion of SOE in } \\
\text { new assessment system is } \\
\text { worthy }\end{array}$ & $\begin{array}{c}408 \\
(8 \mathrm{~V} \%)\end{array}$ & $\begin{array}{c}92 \\
0(1,18 \times 3)\end{array}$ & $\begin{array}{c}500 \\
-0(11,00)\end{array}$ \\
\hline $\begin{array}{l}\text { lusion of OSCE in } \\
\text { ent system is }\end{array}$ & $\begin{array}{c}390 \\
(78.0)\end{array}$ & $\begin{array}{c}110 \\
(22.0)\end{array}$ & $\begin{array}{c}500 \\
(100)\end{array}$ \\
\hline $\begin{array}{l}\text { It is worthy to add a certain } \\
\text { percentage of marks of } \\
\text { formative assessment in final } \\
\text { examination }\end{array}$ & \begin{tabular}{|c|}
443 \\
$(88.9)$
\end{tabular} & $\begin{array}{c}57 \\
(11.1)\end{array}$ & $\begin{array}{c}500 \\
(100)\end{array}$ \\
\hline
\end{tabular}

These are-

Helps in acquiring sound knowledge about subject; Easy to pass \& acquiring more marks in examination because assessment is more specific \& reliable ; MCQ \& SAQ is very much effective for scoring good marks; structured oral examination (SOE) is easier and helpful than previous examination; It is somehow possible to evaluate all students in a same standard; It covers full syllabus ; It is not possible for a teacher to give fail marks if he desire; It makes student busy through out the year with study; If the new system is followed properly, it may produce good quality doctors ; By virtue of adding a certain percentage of mark of formative assessment in final (summative) examination, it is easier to evaluate the labour of whole year.

\section{Weakness of the new assessment method as identified by the students:}

These are-

It is not implemented properly by the teachers of different medical colleges ; Structured oral examination depends on luck ; The purpose of SOE is to evaluate students equally is not full filled; Examinee's of private medical college get more mark in the new system, especially in formative assessment; Some teachers ask questions outside the structure; SOE cannot assess a student's depth of knowledge ; Rules and regulations of new system is not followed by the examiners' and that is not supervised by the university; Even some teachers are not well oriented about how to prepare questions for SOE; It seems to be an experiment; Teachers are not able to orient students regarding the new examination procedure ; In some subject, teachers ask difficult question vindictively in SOE, ignoring the norms of SOE; All students are not evaluated completely \& equally.

Bangladesh Journal of Medical Education 2012;3(1):22-25. 
Table 2. Distribution of the respondents by their opinion about different aspects of written assessment, SOE and OSCE and Formative assessment

\begin{tabular}{|c|c|c|c|c|c|c|}
\hline Statements in relation to written assessment & $\begin{array}{l}\text { Strongly } \\
\text { Agree }\end{array}$ & Agree & Undecided & Disagree & $\begin{array}{l}\text { Strongly } \\
\text { Disagree }\end{array}$ & Total \\
\hline $\begin{array}{l}\text { In new assessment system SAQ in written examination } \\
\text { inclined students to understand the content rather than } \\
\text { memorization }\end{array}$ & $\begin{array}{c}188 \\
(37.6)\end{array}$ & $\begin{array}{l}258 \\
(51.6)\end{array}$ & $\begin{array}{c}24 \\
(4.8)\end{array}$ & $\begin{array}{c}13 \\
(2.6)\end{array}$ & $\begin{array}{c}17 \\
(3.4)\end{array}$ & $\begin{array}{c}500 \\
(100)\end{array}$ \\
\hline $\begin{array}{l}\text { It is easier to pass written examination by memorizing the } \\
\text { answers of a few numbers of questions in new assessment } \\
\text { system. }\end{array}$ & $\begin{array}{c}28 \\
(5.6)\end{array}$ & $\begin{array}{l}35 \\
(7.0)\end{array}$ & $\begin{array}{c}30 \\
(6.0)\end{array}$ & $\begin{array}{c}180 \\
(36.0)\end{array}$ & $\begin{array}{c}227 \\
(45.4)\end{array}$ & $\begin{array}{c}500 \\
(100)\end{array}$ \\
\hline $\begin{array}{l}\text { It is possible to include all content areas in written } \\
\text { examination in new assessment system }\end{array}$ & $\begin{array}{c}85 \\
(17.0)\end{array}$ & $\begin{array}{c}277 \\
(55.4)\end{array}$ & $\begin{array}{c}49 \\
(9.8)\end{array}$ & $\begin{array}{c}67 \\
(13.4)\end{array}$ & $\begin{array}{c}22 \\
(4.4)\end{array}$ & $\begin{array}{c}500 \\
(100)\end{array}$ \\
\hline There is scope of good scoring in MCQ & $\begin{array}{c}193 \\
(38.6)\end{array}$ & $\begin{array}{c}267 \\
(53.4)\end{array}$ & $\begin{array}{c}28 \\
(5.6)\end{array}$ & $\begin{array}{c}10 \\
(2.0)\end{array}$ & $\begin{array}{c}2 \\
(.4)\end{array}$ & $\begin{array}{c}500 \\
(100)\end{array}$ \\
\hline $\begin{array}{l}\text { It is easier to find out the correct answer in MCQ because } \\
\text { alternatives are given }\end{array}$ & $\begin{array}{c}136 \\
(27.2)\end{array}$ & $\begin{array}{c}203 \\
(40.6)\end{array}$ & $\begin{array}{c}46 \\
(9.2)\end{array}$ & $\begin{array}{c}93 \\
(18.6)\end{array}$ & $\begin{array}{c}22 \\
(4.4)\end{array}$ & $\begin{array}{c}500 \\
(100)\end{array}$ \\
\hline \multicolumn{7}{|l|}{ Statements in relation to structured oral examination (SOE) } \\
\hline $\begin{array}{l}\text { Result of examination in SOE in not dependent on the } \\
\text { desire of a examiner }\end{array}$ & $\begin{array}{c}84 \\
(16.8)\end{array}$ & $\begin{array}{c}202 \\
(40.4)\end{array}$ & $\begin{array}{c}54 \\
(10.8)\end{array}$ & $\begin{array}{c}109 \\
(21.8)\end{array}$ & $\begin{array}{c}51 \\
(10.2)\end{array}$ & $\begin{array}{c}500 \\
(100)\end{array}$ \\
\hline $\begin{array}{l}\text { It is possible to judge all students equally (same standard) } \\
\text { in SOE }\end{array}$ & $\begin{array}{c}80 \\
(16.0)\end{array}$ & $\begin{array}{c}218 \\
(43.6)\end{array}$ & $\begin{array}{c}47 \\
(9.4)\end{array}$ & $\begin{array}{c}73 \\
(14.6)\end{array}$ & $\begin{array}{c}82 \\
(16.4)\end{array}$ & $\begin{array}{c}500 \\
(100)\end{array}$ \\
\hline $\begin{array}{l}\text { All students have to answer equal number of questions in } \\
\text { SOE }\end{array}$ & $\begin{array}{c}40 \\
(8.0)\end{array}$ & $\begin{array}{c}215 \\
(43.0)\end{array}$ & $\begin{array}{c}77 \\
(15.4)\end{array}$ & $\begin{array}{c}130 \\
(26.0)\end{array}$ & $\begin{array}{c}38 \\
(7.6)\end{array}$ & $\begin{array}{c}500 \\
(100)\end{array}$ \\
\hline $\begin{array}{l}\text { There is no scope to pass in SOE by knowing nothing or } \\
\text { limited study }\end{array}$ & $\begin{array}{c}59 \\
(11.8)\end{array}$ & $\begin{array}{c}298 \\
(59.6)\end{array}$ & $\begin{array}{c}60 \\
(12.0)\end{array}$ & $\begin{array}{c}57 \\
(11.4)\end{array}$ & $\begin{array}{c}26 \\
(5.2)\end{array}$ & $\begin{array}{c}500 \\
(100)\end{array}$ \\
\hline It is possible to judge a student completely by SOE & $\begin{array}{c}83 \\
(16.6)\end{array}$ & $\begin{array}{c}236 \\
(48.0)\end{array}$ & $\begin{array}{c}70 \\
(13.2)\end{array}$ & $\begin{array}{c}82 \\
(16.4)\end{array}$ & $\begin{array}{c}29 \\
(5.8)\end{array}$ & $\begin{array}{c}500 \\
(100)\end{array}$ \\
\hline $\begin{array}{l}\text { Students phobia regarding oral/viva examination is } \\
\text { reduced by introducing SOE }\end{array}$ & $\begin{array}{c}43 \\
(8.6)\end{array}$ & $\begin{array}{c}210 \\
(42.0)\end{array}$ & $\begin{array}{c}102 \\
(20.4)\end{array}$ & $\begin{array}{c}104 \\
(20.8)\end{array}$ & $\begin{array}{c}41 \\
(8.2)\end{array}$ & $\begin{array}{c}500 \\
(100)\end{array}$ \\
\hline \multicolumn{7}{|l|}{$\begin{array}{l}\text { Statements in relation to objective structured clinical l } \\
\text { examination (OSCE) }\end{array}$} \\
\hline $\begin{array}{l}\text { Students are more attentive in acquiring necessary } \\
\text { practical skill due to OSCE }\end{array}$ & $\begin{array}{c}82 \\
(16.4) \\
\end{array}$ & $\begin{array}{c}246 \\
(49.2) \\
\end{array}$ & $\begin{array}{c}95 \\
(19.0) \\
\end{array}$ & $\begin{array}{c}49 \\
(9.8) \\
\end{array}$ & $\begin{array}{c}27 \\
(5.4) \\
\end{array}$ & $\begin{array}{c}500 \\
(100)\end{array}$ \\
\hline It is possible to judge all necessary practical skill in OSCE & $\begin{array}{c}86 \\
(17.2)\end{array}$ & $\begin{array}{c}300 \\
(60.0)\end{array}$ & $\begin{array}{c}34 \\
(6.8)\end{array}$ & $\begin{array}{c}56 \\
(11.2)\end{array}$ & $\begin{array}{c}24 \\
(4.8)\end{array}$ & $\begin{array}{c}500 \\
(100)\end{array}$ \\
\hline $\begin{array}{l}\text { All students are judged in same standard by examiners by } \\
\text { means of OSCE }\end{array}$ & $\begin{array}{c}44 \\
(8.8)\end{array}$ & $\begin{array}{c}233 \\
(46.6)\end{array}$ & $\begin{array}{c}92 \\
(18.4)\end{array}$ & $\begin{array}{c}104 \\
(20.8)\end{array}$ & $\begin{array}{c}27 \\
(5.4)\end{array}$ & $\begin{array}{c}500 \\
(100)\end{array}$ \\
\hline \multicolumn{7}{|l|}{ Statements in relation to formative assessment } \\
\hline $\begin{array}{l}\text { The marks of formative assessment on daily attendance in } \\
\text { the class make students more interested in attending the } \\
\text { class regularly }\end{array}$ & $\begin{array}{c}55 \\
(11.0)\end{array}$ & $\begin{array}{c}228 \\
(45.6)\end{array}$ & $\begin{array}{c}69 \\
(13.8)\end{array}$ & $\begin{array}{l}108 \\
(21.6)\end{array}$ & $\begin{array}{c}40 \\
(8.0)\end{array}$ & $\begin{array}{c}500 \\
(100)\end{array}$ \\
\hline Satisfied with new assessment system. & $\begin{array}{c}99 \\
(19.8)\end{array}$ & $\begin{array}{c}324 \\
(64.8)\end{array}$ & $\begin{array}{c}38 \\
(7.6)\end{array}$ & $\begin{array}{c}24 \\
(4.8)\end{array}$ & $\begin{array}{c}15 \\
(3.0)\end{array}$ & $\begin{array}{c}500 \\
(100)\end{array}$ \\
\hline
\end{tabular}

Bangladesh Journal of Medical Education 2012;3(1):22-25. 


\section{Dissuasion}

A cross sectional study was conducted among the intern doctors who appear in the new assessment method in final professional MBBS examination, July 2011. Study was carried out to assess the opinion about newly introduced assessment system in final professional MBBS examination according to new curriculum which is implemented in March 2003.

Present study revealed that almost all $95.4 \%$ intern doctors mentioned that short answer question in written examination is better than essay questions, and More than four fifth of the respondents thought that inclusion of MCQ in written examination, and inclusion of structured oral examination in new method is better, about four fifth of the respondents thought that inclusion of objective structured clinical examination (OSCE) in new assessment system is better, and almost ninety percent intern doctors were in favour of the addition of certain percentage of formative assessment's marks to the final examination (Table 1). Current trend in assessment system in medical education worldwide is SAQ, MCQ, SOE, OSCE, and OSLER etc. (Shumway \& Harden 2003). In Bangladesh in undergraduate medical education, there was a change in assessment system in the 2002 curriculum as a part of current trend. Our students' opinion is in favors of this new system.

More than three fourth of the respondents agreed that in new assessment system SAQ in written examination inclined students to understand the content rather than memorizing, and disagreed with the opinion that it is easier to pass written examination by memorizing a few number of questions answers in new assessment method. About three fourth of the respondents agreed with the statement that it is possible to include all content areas in written examination of new assessment method. Ninety two percent of the respondents agreed that there is scope of good scoring in MCQ, and more than two third of the respondents agreed that it is easier to find out the correct answer in MCQ because alternatives are given. One of the important advantages of MCQ is wide content coverage and one of the important disadvantages is Guessing (Sood 1995).

More than half of the respondents agreed that result of examination in SOE is not dependent on the desire of the examiner, and also agreed with the statement that all students are evaluated equally by the examiners in SOE. Fifty one percent of the respondents agreed with the opinion that all students have to answer equal number of questions in SOE. All students did not agree with the above mentioned advantages of the SOE this variation of agreement might be due to that some institutes are not implemented SOE by maintaining standard. About sixty five percent of the respondents agreed with the opinion that it is possible to judge a student completely by SOE, and only half of the respondents agreed with the opinion that student phobia regarding oral/viva examination is reduced by introducing SOE. Over all more than half of the respondents agreed with the different advantages of the SOE.

About sixty six percent of the respondents agreed with the statement that students are more attentive in acquiring necessary practical skill due to OSCE, and more than three fourth of the respondents agreed that it is possible to judge all necessary practical skill in OSCE, on the other hand only $55.4 \%$ of the respondents agreed with the statement that all students were judged in a same standard by examiners by means of OSCE, and $56.6 \%$ of the respondents agreed with the marks of formative assessment on daily attendance in the class make students more interested in attending the class regularly. About eighty five percent agreed with the statement that they are satisfied with the new assessment system

It may be due to lacking in implementation of SOE and OSCE procedure by the teachers appropriately. From the overall study findings it is clear that the newly introduced assessment system has a number of short comings in implementation which needs attention of the teachers and policy makers.

\section{Acknowledgment}

We acknowledge the financial support provided by Director Planning \& Research, DGHS, Bangladesh.

\section{References}

Miller, GE (1977) International Medical symposium, No-2, Rome.23-26 March 1977

Sood, R (1995), Assessment in Medical Education, Trends and Tools, SEARO WHO project WR/IND HRH 001/LCS, New Dellhi-110029, India

Abbat. FR (1980), Teaching for Better Learning, World Health Organization, Geneva

Harden, RM (1986), ASME medical education booklet, No20 , Ten questions to ask when planning a course or curriculum, Medical Education, 20:356

Crooks, TJ (1988) "The impact of classroom evaluation Practices on students' Review of Educational Research, 58438-81

Gibbs, G (1992), Improving the quality of student's learning, Technical and Education services Ltd. Bristol.

Jayawickramarajah PT (1986) Curricular Reform in Medical School, Bahrain, Medical Bulletin 47, 47-53

Srinivasa DK and Kumar S (1996), Assessment of Students, Essentials of Medical Education, Health Learning Materials Centre, Institute of Medicine, Tribhuvan, University Kathmandu, Nepal.

Shumway JM ,Harden RM, AMEE Guide no. 25: The assessment of learning out comes for the competent and reflective Physician. Medical Teacher , 25(6) : 569-585

Bangladesh Journal of Medical Education 2012;3(1):22-25. 